\title{
THE MORLACHS OF DALMATIA DURING THE 15TH AND 16TH CENTURY. A VENETIAN PERSPECTIVE*
}

\author{
DANA CACIUR
}

\begin{abstract}
The article aims to present the main features of the character of the Morlachs living in the Venetian Dalmatia during the Fifteenth and Sixteenth centuries. The research approach focuses on Venetian sources, published and unpublished, therefore the portray of the Morlachs built up in this study is an external one. According to it the Morlachs appear as nomadic people who develop occasional or permanent activities in the Venetian hinterland of Dalmatia. Either they are presented by the sources as shepherds, soldiers, immigrants, merchants, criminals or in many other situations, the Morlachs became agents of coexistence in the permeable area of the Venetian-Ottoman border. This is why, one of the ideas promoted by this study is that the survival of the Morlach`s presence in Dalmatia was assured by the political instability.
\end{abstract}

Keywords: Morlachs, Dalmatia, flexible identities, mobile communities, Venetian perspective, VenetianOttoman border areas

Author: Dana Caciur, "Nicolae Iorga" Institute of History of the Romanian Academy, Institute of History, Bulevardul Aviatorilor 1, București, Romania, dana.silvia.caciur@gmail.com, ORCID iD: https://orcid.org/ 0000-0002-9747-483X

Balcanica Posnaniensia. Acta et studia, XXVIII/1, Poznań 2021, Wydawnictwo Wydziału Historii UAM, pp. $149-175$

ISBN 978-83-66355-68-2, ISSN 0239-4278. English text with summary in English

doi.org/10.14746/bp.2021.28.7

Who were the Morlachs of Dalmatia? This question challenged and provoked many scholars and numerous library shelves were filled with studies aiming to find answers to it. Undoubtedly, there were the numerous archival sources mentioning the Morlachs acting like pieces of a puzzle yet to be completed. With a mostly silent voice the Morlachs themselves did not contribute to a clear and complete historical study, so necessary considering the long period of time they are active in Western Balkans. However, the vivid polemics that still mark this research topic and the opportunities created by the increased mobility of the $21^{\text {st }}$ researchers encourage for some new approaches. The present study aims to present some of the results obtained so far from researching the history of the Morlachs with an approach different of the previous studies. The main characters were the Morlachs, perceived as trans-cultural agents of

* Zagraniczny współpracownik projektu NPRH Wolosi w europejskiej i polskiej przestrzeni kulturowej. Migracje - osadnictwo - dziedzictwo kulturowe (Projekt nr 0604/NPRH3/H12/82/2014). 
the rural Venetian Dalmatia, and the main questions I hoped to answer focussed on what did the Morlachs do in Dalmatia in a specific time frame? What were the consequences of their actions? How did they change during the chosen time frame? Finding answers to these questions one might get closer to the Morlachs realities and even to understand their place in the extended history of the Western Balkans and Eastern Adriatic.

\section{METHODOLOGICAL CHOICES}

Whereas sources relevant for the history of the Morlachs cover almost six centuries (from $14^{\text {th }}$ to $19^{\text {th }}$ centuries if not even from $13^{\text {th }}$ to $20^{\text {th }}$ ) and can be found in more archives a researcher can see in a life time, my choice was to focus on the sources issued between 1409 and 1570. The chosen time frame covers the first period of the Venetian direct administration in Dalmatia, with all its challenges of settling a new administrative system and a new politic and economic approach. Between the inclusion of Zara/Zadar in the Venetian Stato da Mar and the eve of the Cyprus War (1570-1573), Dalmatia was a Venetian outpost oriented toward the great powers of the Central Europe (Hungarian Kingdom) and Eastern Mediterranean (Ottoman Empire). In spite of the wars carried in its proximity and on its lands, and of the almost daily incursions from the neighbouring lands Dalmatia remained on the Christian side of the European world thanks to the strong hands and skilful eyes of the Venetian agents. In order to assure the application of the will and interests of Serenissima the men of the Republic were delegated to govern and administrate the province ${ }^{2}$. The counts and captains, the inspectors, general governors, the captains in Golf or other temporary appointed representatives were essential agents in the functioning of state mechanisms and also for building up the relations with the neighbours. The superior limit of the research was established by the military confrontations that took place in Dalmatia during the War of Cyprus (1570-1573). The main argument for this choice emerges from the territorial, demographic and economic changes determined by the war and reflected equally over the status of the Morlachs. In contrast to the period that followed the Cyprus war marked by an intensive militarization ${ }^{3}$, the time frame covered by the present research

\footnotetext{
${ }^{1}$ I intentionally left aside what was considered the first mention of the Morlachs in Dalmatia, the chronicle of Presbiter Diocleatus given the uncertainties regarding its originality discussed more and more lately. See: Solange Bujan, La Chronique du prêtre de Dioclée. Un faux document historique, "Revue des etudes byzantines" 2008, vol. 66, p. 5-38; Stefan Trajković-Filipović, Inventing a saint's life: chapter XXXVI of The Annals of a priest of Dioclea, "Revue des etudes byzantines" 2013, vol. 71, p. 259-276.

2 Monique O'Connell, Men of Empire. Power and Negotiation in Venice's maritime state, Baltimore 2009.

${ }^{3}$ See: Tea Mayhew, Dalmatia between Ottoman and Venetian rule. Contado di Zara, 1645-1718, Roma 2008; Domagoj Madunić, Defensione Dalmatiae: Governance and Logistics of the Venetian Defensive System in Dalmatia during the War of Crete (1645-1669), PhD thesis, Central European University, Budapest 2012.
} 
is characterized by a relative peace and cohabitation among the locals and among the Venetian, Hungarian and Ottoman officials. The apparent calm from Dalmatia allows an overview of the province as a border area and an identification of the Morlachs as people who inhabit it.

The second methodological choice is represented by the sources I used. Most of the unpublished documents analysed in this research were found in the National Archives of Venice. The attention focusses over the letters exchanged between the central and regional authorities, the complaints of the Venetian subjects from Dalmatia and Istria, and also on the official decisions took be the Venetian Senate and sent to its representatives in Dalmatia to be applied. To these documents were added some letters and agreements issued in various contexts regarding the life on the border of Dalmatia and the encounters with its neighbours, the Hungarian Kingdom and the Ottoman Empire. The use of Venetian documents is also relevant for the history of the $15^{\text {th }}-16^{\text {th }}$ centuries Morlachs because they are the only ones allowing a continue perspective for this time frame, given the fact that the neighbouring states change and also the administrations and rules, while the Morlachs continue to be mentioned by the Venetians in similar contexts. This is also the reason for my choice to build up a Venetian perspective on the Morlachs of Dalmatia letting open the discussion as new sources might complete or change it.

Together with the numerous letters exchanged between Venice and Dalmatia, the research also used the reports written by the Venetian rettori by the end of the mandate and also commissiones in which the doge established the tasks a Venetian official had to complete as representative of the Republic in its over-sea territory. The documents of these two last categories were published by the Croatian historians in Commissiones et relations venetae ${ }^{4}$, by Eugenio Alberi ${ }^{5}$, Maria Pia Pedani ${ }^{6}$ and recently by the members of Stato da Mar project ${ }^{7}$. For the first part of the chosen time frame, the $15^{\text {th }}$ century, I used the Hungarian and Croatian collections of documents published by Šimeon Ljubić ${ }^{8}$, Tadija Smičiklas ${ }^{9}$, Thaloczy Lajos ${ }^{10}$ and others. I also took in consideration various individual studies and researches which ended with the publication of documents.

The third methodological choice applied to my research was the exclusive use of the "Morlach" term/name/ identifier as it was the one used by the Venetian authori-

\footnotetext{
4 Šimeon Ljubić (ed.), Commissiones et relationes Venetae, Zagreb 1877-1880, vol. 2-3.

5 Eugenio Alberi, Le relazioni degli ambasciatori veneti al Senato durante il secolo decimosesto, vol. 3, part 3, Florența 1855 .

${ }^{6}$ Maria Pia Pedani, Relazioni di ambasciatori veneti al Senato. Costantinopoli (1512-1789), vol. 14, Padova 1996.

7 www.statodamar.it. [access: 04.2021].

8 Šimeon Ljubić (ed.), Listine. O odnošajih izmedju južnoga slavenstva i mletačke republike, vol. 2 , 4, 6-7, 9-10, Zagreb 1870-1891.

9 Tadija Smičiklas (ed.), Codex Diplomaticus regni Croatiae, Dalmatiae et Slavoniae, vol. 11-14, Zagreb 1913-1916.

${ }^{10}$ Lajos Thallóczy, Hondika Antal, A horvát véghlyek oklevéltára 1490-1527, Budapesta 1903.
} 
ties. The term "Vlah" is also used but only in those cases in which the equivalence Morlach=Vlah was supported by the Venetian and Hungarian or Ottoman (their translation in the Venetian dialect) documents speaking about the same subject. Firstly, the "Morlach" term is the one used in the Venetian documents every time they referred to this people, the issuers of the documents replacing the interest for the ethnical composition with the one for the assurance of a peaceful atmosphere in Dalmatia. Secondly, the used documents, many of which are relatively small, are part of the correspondence among the Venetian officials and had as main objective to solve the problems caused by the Morlachs or to answer some of their needs, while very few are addressed directly to the Morlachs, case in which we speak about a translation without mentioning in what or form what language. Thirdly, is also very relevant for the choice I made the fact that I could not find Morlachs written sources speaking about themselves or offering a narrative of their origin.

The definitions given by the historians support the idea of a common Vlach origin for the Morlachs, but the events of the $14^{\text {th }}, 15^{\text {th }}, 16^{\text {th }}$ and $17^{\text {th }}$ centuries that put in movement people from the inner Balkans toward the Adriatic and/or the North-West and the probability that some other groups defined from an ethnical point of view, with the modern meaning, as Serbians, Croatians, Greeks, Dalmatians or others might have chosen a pastoral life an perceived afterword by the Venetians as Morlachs are equal aspects that demand caution. Since my goal was not to explain or to support an ethnical definition of the Morlachs I chose to use the discovered documents to enrich the information about this very active people from the West Balkan Peninsula for a specific time frame.

\section{BEING A MORLACH FROM THE VENETIAN POINT OF VIEW}

As mentioned above, the sources mentioning the Morlachs are rather short and poor in details. They are almost exclusively Venetian and record the Morlachs activities in contexts that challenge the good administration of the province. If at the level of the bigger actors the peace agreements settled the ideal relationships, at the local level with daily encounters the involved actors pay more attention to the elements threatening the desired peaceful coexistence. In a region like Dalmatia, mountainous and divided by local parties supporting one power or another (the filo- and anti- Venetian political trends during the common border with the Hungarian Kindom) or narrowed by the Ottoman military offensive toward the Adriatic, the Morlachs appear nothing more than another potential element for conflict. Unlike other possible causes for conflict the Morlachs presence was the less feared one. It happened because they were already a common presence and the Venetians learned very quickly what they usually did and how to deal with them. All the contexts mentioning the Morlachs help to create a set of activities which became in the Venetian eyes features for their communities. Therefore, from the Venetian perspective the Morlachs were those who arrived in 
Dalmatia from beyond the mainland border; they were shepherds, merchants, malefactors, immigrants, colonists, soldiers etc. One Morlach or group of Morlachs could develop one or more of these activities, but they certainly originated beyond the border of Dalmatia. Aspects like religion, language and ethnicity (with the modern sense) could not be supported by the analyzed sources, these being mainly administrative and external so they did not find essential to have them mentioned.

\section{CHALLENGING THE DIPLOMACIES OF THE BORDER}

First of all, for the Venetian officials the Morlachs always arrived from beyond the border. Issuing administrative documents focussing of the solution, they rarely mentioned the place from where the Morlachs came, but depending on the period, they arrived either from the Hungarian possessions (Bosnia, Croatia, etc.), either from the Ottoman ones. At some point the origin was not even important since the Morlachs stayed in Dalmatia only for short terms: days, weeks or couple of months. However, there are some aspects worth to be discussed when we encounter the Morlachs as cross-borders, others than the shepherding and commerce which are analysed separately.

Without being described as a succession of delimitation marks, the border ${ }^{11}$ of Dalmatia between 1409 and 1570, even if it had a very well establishment of its place, appeared as a space easy to cross by subjects and officials of the neighbouring states. This border area became a space of intersection of people, allowing the mixture of different communities, with different lifestyles or religions. This way was created a hinterland where "the others", refugees from the territories affected by war" ${ }^{12}$, had to adapt to the rules of the locals and to find ways to maintain their specifics. At the formal level the Venetian administration usually used in many of its documents the phrase "good neighbourhood" (neighbourliness, per vicinar bene) a clear statement that the border had to be respected without excluding the coexistence of the subjects. Moreover, the geography of the province, predominantly mountainous played its contribution in transforming the region in an appropriate space for the survival of a population easily adaptable in difficult political conditions, which in the Morlachs case was a feature for their identification in the eyes of the Venetians.

Equally for the time when Venice disputed its limits in Dalmatia with the Hungarian Kingdom, but mostly with the Ottoman Empire the Morlachs were present in the province as inhabitants of small villages (catuns) or regular Dalmatian villag-

${ }^{11}$ It is rather defined as an open space and not a delimitation line, concept detailed and explained better in: Maria Pedani, The Ottoman-Venentian border (15th-18th centuries), Venice 2017; Daniel Goffman, The Ottoman Empire and Early Modern Europe, Cambridge 2002; Nora Berend, At the gate of Christdom: Jews, Muslims and "Pagans" in medieval Hungary, c. 1000-1300, Cambridge 2001.

12 Borna Fuerst-Bjeliš, Imagining the Past: Cartography and Multicultural Realities of Croatian Borderlands, in Cartography-A tool for Spatial Analysis, ed. Carlos Bateria, Porto 2012, p. 299. 
es. However, when it comes to discuss about the Morlachs as border inhabitants is essential to place them in the larger context of border negotiations, with their endless misunderstandings regarding the belonging of one village or another. In this context the Morlachs appear as inhabitants, temporary or permanent, of some villages without having their status officially recognised as subjects of one state or another. In most of the cases however they were the subjects of the other power than the one to whom the village rightfully belonged. ${ }^{13}$

Some important differences have to be mentioned for a better understanding of what meant and caused the Morlachs living in the Venetian administrated hinterland without recognising it authority. Before the fall of Bosnia, the Morlach presence in Dalmatian villages was discussed and negotiated with the counts of the Hungarian Crown. Mostly the reasons were the damages made by the Morlachs, or Vlachs as they are mentioned by the Hungarian Latin documents. It happens in $1412^{14}$, when the captain of Zadar prepared 3000 ducats to organize a military incursion for driving away the Morlachs who entered in Ostrovica. Under the command of an emin named Sandallor the Morlachs occupied the castle and made damages in the surrounding areas. As the „honor of the state and the silence of the province had to be respected”, the captain of Zadar had to remove the Morlachs and to increase the defence system of the province if the budget allowed it. In July $1436^{15}$ the ban of Slavonia, Matkó Tallóci (1436-1445) ${ }^{16}$ was the one who interfered in stopping the Vlachs from doing damages in the Venetian lands. With an official decree the ban forbid all the Vlachs, from all its territories, living in catuns or on king`s lands, soldiers or of any other kind to plunder in lands of Serenissima under the threat of punishment. In another occasion, at $31^{\text {st }}$ of October $1450^{17}$, Francesco Foscari, the doge, dispatched to the count and captain of Šibenik, Christophoro Marcello, a letter to answer at the complaints brought to Venice by the delegates of Šibenik, Ambrogio Michetich and Michele Simeonich. The third point of the letter concerned the Morlachs and some other neighbours who used to make damages in the town's hinterland. These Morlachs, Croatians and others living in the mountains were bad people (homines malae vitae et conditiones) who made their living by plundering the Dalmatian lands and could not be stopped in any other way than by not being granted safe-conducts ${ }^{18}$ anymore. For the satisfaction of the Šibenik's delegates the doge ordered to his officials from Dalmatia not to issue this type of documents for the Morlachs no matter the reason. Unfortunately, since the Venetian subjects used to travel in the Croatian lands without safe-conducts the Morlachs and the Croatians decided not to respect the decision. In order to solve the different the rettori asked the Venetian Senate to be allowed to judge and punish the

\footnotetext{
13 Šimeon Ljubić, Listine, vol. 9, p. 89.

14 Ibidem, vol. 6, p. 239-240.

15 Ibidem, vol. 9, p. 89.

${ }^{16}$ Engel Pál, Magyarország világi archontológiája 1301-1457, vol. 1, Budapesta 1966, p. 26.

17 Vincenzo Miagostovich, Per una cronaca Sebenicense, "Rivista Dalmatica" 1908, vol. 4, no. 2, p. $161-189$.

${ }^{18}$ Ibidem.
} 
Morlachs who made impossible the life in the area (absque terris vestris vivere non possunt). The Senate's answer was positive. Again in $1453^{19}$, the counts of Krbava, Toma and Paul, wrote to the doge Francesco Foscari to assure about their intention in keeping the village Chlicevaz and the other lands of Venice far from scandals and acts of violence that might have been caused by their subjects. To keep the good relations of friendship, they promised to stop the Morlachs, who rebelled even against them, to damages the Venetian hinterland.

The arrival of the Turks in the proximity of the border changed and diversified the contexts in which the Morlachs crossed the border presence. In the new situation, the matter of establishing a common border between the provinces of the Venetian Republic and the Ottoman Empire could start to be discussed only after the end of 1499-1503 ${ }^{20}$ war. Up to this moment, the often Ottoman incursions and the ongoing offensive did not allow many respites for negotiations. Once the peace treaty from 1503 was signed Venice became aware that having a territory on land in the immediate proximity of the Ottomans would have caused a permanent threat. Since the powerful neighbour couldn 't be driven away, the settlement of some borders and rules to cross them had to be done. Before the beginning of a new war in 1537, a number of four agreements with the Ottomans war signed ${ }^{21}$. According to them the border issue was solved as it follows: the subjects of the Sultan were forbidden to cross the border and to make damages in the Venetian lands, as it was established for the Venetian subjects tempted to do the same. Such a formulation echoed in a task for the regional officials in charge to negotiate and describe the border, efforts carried away until the beginning of the Cyprus war. In this context the Morlachs played a very important role since they were the ones who kept alive the misunderstandings regarding the possessions of some villages of mainland Dalmatia. The sources mention a number of 33 villages in the hinterland of Šibenik and three in that of Trogir inhabited by the Morlachs, Ottoman subjects, even if the villages belonged according to previous documents $^{22}$ to the Venetian territory. A resume of the negotiations for the borders and vil-

19 Listine, vol. 10, p. 9-11.

20 Bernard Doumerc, L'Adriatique din XIII'me au XVI'eme siecle, in: Histoire de l'Adriatique, ed. Pierre Cabanes, Paris 2001, p. 283: the peace of Buda of 1503 settled a modus vivendi in which Venice had the role to protect the free circulation in Adriatic.

21 Between 1503 and 1537 were concluded the following Venetian-Ottoman agreements: in 1503 Instrumentum Reciprocum published in Hans Peter Alexander Theunissen, Ottoman-Venetian Diplomatics: the 'Ahd-names. The Historical background and the development of a category of political commercial instruments together with an annotated edition of a corpus of relevant documents", "Electronic Journal of Oriental Studies" 1998, vol. 1, no. 2, p. 377-392; in 1513 - capitulation in ibidem, p. 394-399; in 1517capitulation in ibidem, p. 400-414; in 1521 - capitulation in ibidem, p. 415-436.

${ }^{22}$ A relevant example was the list of documents written by Daniele di Ludovico in July 1531 which contains more than ten documents issued by the kings of Hungary, Bosnia, or other powers in Western Balkans. He created this list to help the negotiations for the border of Dalmatia and to prove the appurtenance of the villages from the hinterland of Šbenik and Trogir among the Venetian possession; Archivio di Stato di Venezia [ASVe], Lettere e scriture turchesche, fl. 1-2. 
lages of Šibenik is contained in a description ${ }^{23}$ written sometime between 1566 and 1568. The author, supposed to be Francesco Difnico, gave a special attention to the villages from this hinterland occupied by the Morlachs after the Ottoman conquest of Skradin (1522). The villages abandoned by the Venetian subjects ${ }^{24}$, driven away by the fear of the Turks, attracted the Ottoman subjects willing to exploit their resources. The discontent of the rightful owners was obvious and the discussions for their release could not be avoided. They lasted for the entire period until the beginning of Cyprus War, but some significant shifting points helped Venice not to lose the rural Dalmatian hinterland for good.

Such a moment, emphasized by the author of the 1566-1568 description, is represented by the negotiations carried by Piero Zen, count and captain of Šibenik, with Husrev beg, the sanjack-bey of Bosnia. The controversies started with the Venetians complaining about the decision took by the spahis to settle the Morlachs in the Venetian territories. A compromise was reached in 1525, when the Ottoman side accepted to remove its subjects letting the lands in the hands of Venice ${ }^{25}$. The Ottoman official even sent an arz to the Porte to inform about the closure of the dispute. Once solved the dispute at the official level this did not mean it ended. It continued because the Morlachs travelled to Šibenik and concluded private contracts, approved by the count, with the owners of the villages and lands promising them a fifth of the crops and animals, in exchange for the right to use the pasturelands and the waters ${ }^{26}$. Unfortunately, this collaboration did not work because the Morlachs chose not to fulfil their obligations: they only gave animals to the landlords without sowing crops ${ }^{27}$. Since they did not leave the villages nor were driven away when the Ottomans registered their possessions of Croatia $^{28}$ the Morlachs declared the villages as their own, recalling the renting contracts. Consequently, they were registered as owners of possessions of the Porte. With the complaints of the rightful owners, many letters begun to be exchanged by Venice with the Porte and many decrees stated the removal of the Morlachs ${ }^{29}$. Since this removal had to be done by the Ottoman functionaries, they either refused or delayed it application arguing for the decrease of incomes in the region and for the belonging of the villages to the Sultan`s lands.

After a visit of the kadi of Klis a new arz confirmed the Venetian right over the villages (probably in 1557). Two trustworthy men from Šibenik were appointed by the count, at the request of Venice, to travel to Constantinople to inform the bailo about what has been decided and to ask him to require the deletion of the Venetian villages from the Ottoman registers ${ }^{30}$. Arrived in Constantinople Michel Lucich, one of the am-

\footnotetext{
23 Š. Ljubić (ed.), Commissiones, vol. 3, p. 238.

24 Ibidem, p. 239.

25 Ibidem, p. 239 (anonim).

26 Ibidem, p. 239.

27 Ibidem, p. 240.

28 Ibidem, p. 240.

29 Ibidem, p. 240.

30 Ibidem, p. 241.
} 
bassadors met the opposition of Achmat Celebi, the secretary of emin Zatalovich, who registered the borders. New negotiations were carried by the ambassador Domenigo Trevisan and a new decree for the removal of the Morlachs was issued. When this new decree arrived in the hands of the sanjack-bey of Klis, he refused to apply $\mathrm{it}^{31}$ saying that it did not mention the removal of the Morlachs but it just confirmed once more the villages to the hinterland of Šibenik. To remove them was required a new arz from the capital. New travels were made and beautiful gifts were sent from Venice, but all for nothing.

In his turn Marino di Cavalli, the successor of Domenigo Trevisan as bailo in Constantinopole, managed to obtain a final decree. According to it Mustafa bey, sanjack-bey of Klis, was in charge to release the villages. At the end of his mandate while returning to Venice, Marino di Cavalli made a stop in Šibenik where he hopped to meet the sanjack-bey. Since he was left for a campaign in Hungary, Marino Cavalli asked Paulo Marcello, the count and captain of Šibenik, to remind to the Ottoman official about the decision to remove the Morlachs and about a compensation of 1100 cechini $^{32}$. Piero Zavoreo from Šibenik was the one who encountered Mustafa bey, the sanjack-bey of Klis. The meeting took place in Livno and ended with the sanjack-bey's promise that he will proceed with the removal of the Morlachs and the restitution of the villages. The following day however, the messenger of Sibenik was caught up by a messenger of the sanjack-bey who announced him that the Ottoman official changed his mind, and that he could not make what he promised without seeing an official document ${ }^{33}$. Zavoreo returned to the sanjack-bey and demanded an Ottoman companion to go to Šibenik where they could make an official copy of the decree received by Cavalli in Constantinople. Neither this new copy nor the new gifts sent to the sanjack-bey solved the Morlachs issue. This time the motives emphasized some very clear economic interests. Invoking the lack of another territory to settle the Morlachs the Ottoman representative refused to apply the decisions favourable for Venice. Mustafa bey said it would have been difficult to move a large number of people, their goods and animals, and to recover the annual incomes obtained on their behalf, income that would have surpassed the amount of 1000 cechini as it was discussed as compensation ${ }^{34}$. This report written to resume the historical evolution of the events regarding the restitution of the border villages to Šibenik and the removal of the Morlachs ${ }^{35}$ ends in a very compassionate key "poor inhabitants of Šibenik, own-

\footnotetext{
31 Ibidem, p. 241.

32 Ibidem, p. 241 (anonim); the information was written in the documents issued by the Senate at the $2^{\text {nd }}$ of March 1560: ASVe-Collegio. Lettere secrete, fl. 22.

33 Š. Ljubić (ed.), Commissiones, vol. 3, p. 241 (anonim).

34 Ibidem, p. 241.

35 According to Kristijan Juran, Doselavanje Morlaka u opustjela sela šibenske Zagore u 16. stoljeću, "Povijesni prilozi" 2014, no. 46, p. 129-160, the Morlachs who settled these villages belonged to the following families: Mirilović, Radohnić şi Vojihnić. Their presence in the hinterland of Šibenik is explained by the author as part of the Ottoman settlement process. The study offers indeed useful information regarding the settlement of Morlach families/clans in abandoned villages from Dalmatia transforming
} 
ers of so many villages and over the beautiful and fertile field of Velino have now so few possessions on land" 36 .

The case study of the 33 villages from the hinterland of Šibenik, presented here very shortly, suggest the difficulty and intricate relations between the bigger and smaller actors involved in administrating a border region and with the subjects of the neighbouring states already involved in a long coexistence. The new immigrant waves arriving from the Ottoman Empire during the first decades of the $16^{\text {th }}$ century required space to settle and built communities ${ }^{37}$ and abandoned villages of Dalmatia appeared to be the ideal place. Once ended the military confrontations, the former land owners reclaim their possessions invoking their right since the times of the Hungarian kings. Therefore, the negotiations for the appurtenance of the Dalmatian villages affected by war became border negotiations.

The interests of the two neighbouring states and furthermore the ambitions of their local representatives did not allow half measures: without these villages the hinterland of Šibenik would have been too narrow for the Venetians, while the Ottomans would have lost their advantage. This is how the Morlachs became the pretext used by the both sides to justify the territorial expansion ${ }^{38}$. It is clear that until the war of Cyprus the negotiations did not reach a conclusion, or after this new war it didn't even matter since new conquests were made by the Ottoman troupes. However, for a short period of time, Šibenik got back the 33 villages but only in exchange for some others given to the Ottomans in areas closer to their territory ${ }^{39}$.

To this form of crossing the border in order to exploit the resources of the neighbour the documents place the Morlachs in a few other cross-border situations. Firstly, the Morlachs are mentioned being involved in protecting the Venetian border and in assuring the safety of the region. This change of sides was mostly encouraged by the Ottoman decision to limit the freedom and privileges of the Christian troupes and to impose them taxes similar to those paid by the rest of the Ottoman subjects ${ }^{40}$. Therefore, the Morlachs could be found among the Venetian troupes of stratioti ${ }^{41}$, sta-

them in catuns. Howevere, the reactions of Venice and the numerous letters exchanged with the representatives of the Porte, suggest a clear and determined intention of Serenissima to keep, recover and reconquer the rural hinterland of Dalmatia, the needs of province making impossible any alternative.

36 Š. Ljubić (ed.), Commissiones, vol. 3, p. 242 (anonim).

${ }^{37}$ Kristijan Juran, op. cit., p. 129-160.

38 Tommaso Stefini, Irregularità e raporti di forza nella Dalmazia del Cinquecento,"Studi Veneziani"” 2010, vol. 59, p. 632.

39 Angelico Alacevich, Pagine della storia di Sebenico, Tipografia del comando truppe Dalmazia (24 divisione), Šibenik 1920, p. 87.

40 Tommaso Stefini, op. cit., p. 635.

41 Vladimir Lamansky, Secrets d'Etat de Venise. Documents extraits notices et etudes servant a eclaircir les rapports dela Seigneurie avec les grecs les slaves et la Porte Ottomane a la fin du XVe et au XVIe siecle, Saint-Petersbourg 1884, p. 556. In September 1524 the Venetian Senate ordered to complete the troupes by enrolling 3000 soldier from the Venetian subjects of Istrian, Dalmatian, Slavic, Morlach, Albania and Greek nations; ASVe, Senato Deliberazioni Mar [SDM], fl. 43: the inspector Antonio Diedo found in June 1553 in Vrpoglje forts three Morlachs, two as soldiers and one as gun-man, but all of them declered themselves as Venetian subjects even if they were born in the Ottoman territories. 
tus of importance when it comes to understand the coexistence with the locals and the relations built with the regional representatives of the Venetian military system. Consequently, the Morlachs are mentioned in the Venetian documents as protectors of forts, fortresses, castles and city gates, while they also continue to be victims of the Ottoman incursions on whose behalf are recompensed the Venetian soldiers ${ }^{42}$.

Another aspect of the Morlachs status as border inhabitants, worthy to be shortly mentioned, is given by their relations with the Uskoks. Letting aside the fact that a large share of the historiography granted them a common origin and even identity, I want to stress over the significance of the relations between the Morlachs and the Uskoks from the perspective of the Venetian Ottoman negotiations for the eastern Dalmatia. These relations are visible through the accusations of complicity in plunder actions. Either this complicity was real, but not exclusively limited to the Morlachs involvement, or simple diplomatic strategy of the Ottomans to keep Venice alert the Dalmatia it had a great impact over the local and even central diplomacy and administrative decision making. This complicity reflected in most of the cases through the pray incursions of the Uskoks and the share of pray after words. On the other side, the Morlachs were victims of the Uskoks. Either they lose their lives, goods or animals, as victims of the Uskoks the Morlachs put the Venetians in difficulty when it comes to protect the neighbourliness and the subjects of the good neighbour.

\section{IMMIGRANTS}

Maybe the most important feature of the Morlachs from Dalmatia was their status as immigrants. This aspect can be understood through the Venetian settlement policy which in the case of the Morlachs met more forms of applicability. First of all, the most interesting is the case of morlacchi istriani ${ }^{43}$, as were named by the sources the Morlachs settled in the hinterland of Zara/ Zadar during the war of 1537-1540. This case study offers a singular example, for Dalmatian hinterland, of Venetian involvement in convincing Morlachs to settle in its jurisdiction and to try including them in the administrative system of the province. The evolution of this community during the $16^{\text {th }}$ century allows the analysis of a set of directions meant to understand the trans-

42 ASVe, SDM, fl. 5: Christophoro de Nassi was rewarded in August 1547 for his services defending the Venetian hinterland of the incursions of the Uskoks, Morlachs or the Martolossi; ASVe, SDM, fl. 4: Nicolo Grecopolo lieutenant of chivalry was rewarded in October 1547 for recovering two Morlachs, Ottoman subjects from the Uskok hands; ASVe, SDM, fl. 13: Thodero Borsa was rewarded in April 1555 for interventions against the Morlachs che sono venuti a dannaziar sopra questi confine; ASVe, SDM, fl. 42: Bernardin Dara from Coron was rewarded at $11^{\text {th }}$ of September 1569 for being involved in driving away the Morlachs (et massimamente nel cacciar Morlacchi fuori che ossupavano di continuo quell contado).

43 I published an extended case study about this topic in Silvia-Dana Caciur, Migrații spontane și organizate în teritoriul Zarei (Zadar-ului) la mijlocul secolului al XVI-lea. Cazul Morlacilor Istrieni, "Studii şi materiale de istorie medie" 2016, no. 34, p. 73-104. 
formation of the Morlachs from an ethnic group to a social one without excluding elements specific for one or another.

Similar to the Morlachs shepherds who received the right to use the public pasturelands and water courses, or like the Morlachs who are accepted in the town markets of Dalmatia, so did the Morlachs who accepted to move in Dalmatia. During the Venetian-Hungarian neighbourhood, the diplomatic discourse concerning the Morlachs focused on their status as subjects of the Hungarian crown or/and noble families and their needs. The increased taxes and the impossibility for these Morlach/ Vlach communities to develop inside the Hungarian kingdom intensified their transfer in the Venetian hinterland where the status as newcomer was more favourable. Because of that we can say that these regional inter-state migrations reflected on the border of Dalmatia a phenomenon common in Balkans. The Morlachs arriving in the Venetian jurisdiction were already a common presence in the Western parts of the Saint Stephen kingdom. Over these strata new Morlach waves would have settled once the Ottoman offensive found its course toward the Adriatic.

At the beginning of the $16^{\text {th }}$ century, Morlach migrations in the Dalmatian hinterland have their source from the communities living near the border region. The Ottoman raids and offensive were the main reasons for these people displacements ${ }^{44}$. The Morlachs transfer from the Croatian lands in the Venetian ones, become in time something permanent that had to be controlled by the local authorities in order to stop or to successfully administrate the new arrivals. The rettori of Zara were those who at the $1^{\text {st }}$ of December $1529^{45}$, wrote to the Venetian Senate to ask for solutions at the problems created by the Ottoman incursions. Their decision was influenced by the numerous letters sent by the inhabitants of Dalmatia (written in Serbian and Slavic: lettere in servo et in schiavo), in which they complained about the miserable life they have since the Ottoman begun to raid their villages and lands. However, in this particular case the reason for the general discontent were not the plunders and the people kidnapped to be sold as slaves but the damages caused by the refugees from the Ottoman lands. These refugees, fearing the Ottomans, who conquered Krbava and Segna, chose to abandon their lives and to start a new one in the shadow of Serenissima. The mentioned document presented the example of Clococich, which together with his family settled in Skradin. Even if this family promised to live in that village until Christmas 1529 the rettori of Zara showed their distrust and fear for they might be staying longer. The reason for not trusting Clocotich family resided in the fact that they even if had a house near Narenta (in southern Dalmatia) they chose to live in, at that time, the Venetian Dalmatia. The attitude of the officials was justified given the efforts they had to do to include the refugees in the life of the province. On the other side, equally jus-

44 ASVe, Lettere secrete, b. 4: at $5^{\text {th }}$ of September 1515 the Venetian Senate asked the bailo in Constantinople to obtain from the Sultan a decree/an arz addressed to the Ottoman officials from the neighbourhood of Zadar to forbid them entering the territories of Ioan of Krbava. The Ottoman raids set the population in movement and consequently affected the relations between the Venetians and the Croatians.

${ }^{45}$ ASVe, Capi del Consiglio dei X [CCdX], b. 283. 
tified was the decision of the refugees: the Narenta hinterland was probably even more insecure than the region of Krbava or Segna, given the Uskok presence (before 1537) and the Ottoman offensive. Because of that a large family would have preferred the safety of the Venetian state to an Uskok life style or to a new relocation once Narenta would have become the Ottoman access point in Adriatic.

It appears that a clear distinction was made between the incursions for plunder and these types of border crossings. Venice had to deal with them in a different way and to find specific solutions in order to transform the damages in advantages or at least to diminish them. The mentioned differences emphasize the specifics of the Morlach communities (open to fight but attached to the family) and also the ways followed by Venice to protect the border and to solve the demographic challenges ${ }^{46}$. The settlement of a few thousands of Morlachs ${ }^{47}$ for the entire time frame is a clear answer to these permanent problems of Venetian Dalmatia.

However, the main effect of the increasing immigrant waves was to stimulate the Venetian settlement policy as a state policy. In the Venetian case, this policy resumed mainly at transferring the immigrants in Istria. The solution was administrative since Istria was fighting a strong depopulation, while Dalmatia became too crowded with immigrants and individuals entering for pray. Also, this overpopulation of Dalmatia was solved by the transfer of people in Istria because the newly arrived did not respect the rules and laws of Venice and also did not fulfil their status as guards of the border against the Ottomans, their former lords. When these inconveniences happened in Istria they became a matter of internal organisation ${ }^{48}$. The experience acquired in Dalmatia in dealing with the Morlachs helped the authorities from Istria to equally satisfy the need of the locals and those of the Morlach settlers. However, in spite of all the efforts, the Morlachs settled in Istria, like the Morlacchi istriani from the hinterland of Zadar continued their specific life style: were shepherds, kept their traditions and beliefs and demanded to be granted with similar benefits. In time, once the higher stability of Istria managed to influence the Morlachs some changes could be observed. Without a direct ottoman influence, having agricultural fields, markets to sell their products and authorities to assure their protection the Morlachs begun to act as subjects of the Venetian state. This strange process of assimilation that took place in

46 This was even more important since there were Venetian subjects willing to pass in the Ottoman lands and to become Muslims and subjects of the Sultans. See: Klemen Pust, "Mi faccio Turco". Migrations from the Venetian to the Ottoman territory and conversions of Venetian subjects to Islam in the Eastern Adriatic in $16^{\text {th }}$ century", in: Adriatic frontiers: communications across cultures, space and rime, la Mediterranean Programme $11^{\text {th }}$ Mediterranean Research meeting, Florence and Montecatini terme 2010, pp. 29; Klemen Pust, "Le genti della citta, delle isole e del contado, le quale al tutto volevano Partirsi". Migrations from the Venetian to the Ottoman territory and conversions of Venetian subjects to Islam in the Eastern Adriatic in 16 ${ }^{\text {th }}$ century, "Izvorni znanstveni rad" 2011, vol. 40, p. 121-159.

47 Angelo de Benvenuti, Storia di Zara dal 1409 al 1797, Milano 1944, p. 106.

48 See: Tomaso Caenazzo, I Morlacchi nel terriotiro di Rovigno, in: Atti e memorie della Societa Istriana di Archeologia e storia patria, Parenzo 1885, p. 129-140; Lia de Luca, Venezia e le immigrazioni in Istria nel Cinque e Seicento, $\mathrm{PhD}$ thesis, Universita Ca'Foscari, Venice 2011. 
Istria justify up to some extent the Morlacchia Istriana name gave by some scholars ${ }^{49}$ to the areas settled by the Morlachs.

\section{SHEPHERDING}

Another very important category of the activities in which the Morlachs were involved according to the Venetian sources is represented by shepherding and the practice of a semi-nomadic transhumance. These specific activities and the implicit life style were, and still are, very popular in identifying the Morlachs of $15^{\text {th }}-16^{\text {th }}$ centuries. The Morlachs shepherding is also connected, through many common elements with the shepherding traditionally attributed to the Vlachs spread all over the Balkan Peninsula and further to the southern Poland ${ }^{50}$. Questioning however the role played by the transhumant shepherding in the survival of an ethnic group in the Balkans, the research of the Morlachs shepherds history has to be connected with the changes taking place in that time.

Unfortunately, the Venetian sources do not allow us to establish an exclusivity of the Morlachs being shepherds in Dalmatia nor to argue for all the Morlach shepherds being exclusively Vlachs. Their evolution during the considered time frame can be analyzed through the impact over the communities they affect with their flocks. Whether there are many documents suggesting a predilection for grazing sheep and for the reverse transhumance, as it was named by Fernand Braude ${ }^{51}$, they do not offer more information but mostly mention the presence of the Morlach shepherds in the fields and crops of the inhabitants of Dalmatia by using phrases like: "the Morlach shepherds did damages", "the Morlachs flocks destroyed the crops" or "the Morlach shepherds are forbidden to...". Together with some other, more extended information, these short notices help to observe the functionality of the Morlachs shepherding.

It is nevertheless connected with the Vlah shepherds from inner Balkans. The rules they have to respect, the obligations they have to fulfil, the cycle of their presence in Dalmatia, the organization in small villages (catun) leaded by catunari and the products resulted from grazing sheep are all reasons to think of the Morlachs like Vlachs. In Dalmatia the Morlach shepherds could be met during the winter months, between November and April. For these six months the Morlachs use the fields of the locals to feed and water their flocks. As reserves of hay were not found mentioned in documents it is clear that the public pasture lands, the rented ones or those situat-

49 Nicola Antolini, Slavi e Latini in Istria tra cinquecento e novecento: origine storiche e problem del contest multi-etnico istriano, "Storicamente" 2006, vol. 2, p. 1-54 (DOI: 10.1473/stor356 - digital journal).

50 Miloš Luković, Self-government institutions of nomadic and semi-nomadic livestock breeders in the Balkans and in the Carpathian regions in the late medieval and early modern periods, "Res Historica" 2016, vol. 41, p. 51-94; and others.

${ }^{51}$ Fernand Braudel, Mediterana și lumea mediteraneană în epoca lui Filip al II-lea, Bucharest 1985 , vol. 1, p. 166. 
ed far from the towns were not enough to feed the flocks. Similarly, were the things for the water sources. Both these aspects suggest a tense situation difficult to control. Also, the months spent by the Morlach shepherds in Dalmatia were appropriated for concluding some commercial collaboration or for renting some lands and to create bridges for cultural exchanges, if necessary. Pastoral transhumance used to be for the Morlachs another element that allowed them to adapt to different political systems. The transformations caused in Dalmatia by the Venetian-Ottoman neighbourliness facilitated in the same time the survival of a traditional way of life and to the acceleration of the Dinaric Vlachs integration in the Dalmatian society.

\section{MERCHANTS}

The involvement of the Morlachs in the commercial life of Dalmatia is another aspect that contributes to the Venetian definition of the Morlachs, and also to their evolution and transformation in the context of the measures took by Venice in order to include Dalmatia in Stato da Mar. This is why the Morlach trade is connected to the Venetian policy of the economic uniformity of the province and its adjustment to the central interests. Through its delegated officials, Venice controlled most of the resources of the province. The existing resources were not too many or too varied but allowed a selfsufficient life style for the locals. Mostly, the hinterland of Dalmatia was used for the cultivation of the vinery, olives and a smaller part for the cereals. The fields and the crops influenced the grazing of small animals and also the bees. On the other side, the proximity of the sea offered to the Dalmatian people significant quantities of fish and salt (produced in salt pans).

Situated between two of the great economic powers of the Adriatic, Venice and Dubrovnik, the Dalmatian towns did not gather the necessary straight to develop an autonomous maritime commerce. This might be one of the aspects that made the towns of coastal Dalmatia to focus on the local trade with which to interfere in the bigger game of the commercial exchange. Nevertheless, the role played by Dalmatia in keeping safe the Venetian monopoly in Adriatic was an essential one. If at the beginning, getting Dalmatia in the Venetian area of interest meant to transform it in a barrier against the Hungarian expansion and for the economic interest of the other Christian states. After 1563 Dalmatia granted Venice with some very attractive opportunities regarding the use of the markets from inner Balkans. In spite of all the frictions and military encounters, the commercial relations between Venice and the Ottoman Empire looked after some solutions for coexistence. These solutions aimed for maintaining the peace and to assure a reciprocal protection ${ }^{52}$. At 'bigger' politic level (between de Doge and the Porte) the Venetian Ottoman economic collaboration can be analysed

52 Eric Dursteler, Commerce and Coexistence: Veneto-Ottoman trade in the early modern Era, "Turcica" 2002, no. 34, p. 106. 
through the capitulations concluded, through different Ottoman decrees in favour for Venice or through different other 'perks' won by the Venetian representatives active in Constantinople. To these it was added a good division of the responsibilities regarding the use of the maritime space: Venice had the commercial routes, the technological and naval know-how and assured the protection of the commercial ships, while the Ottomans assured the markets for provision and sale.

On the other side, at the regional level, the Venetian-Ottoman commercial relations recall some of the 'neighbourliness ' principles. In Dalmatia, Venice had its longest border on land with the Ottoman Empire fact that required an adaptation to the commercial regulations between the two states to the inland specifics. Accordingly, the trade with the Balkan markets was essential and the Morlachs were among its agents. Moreover, the Ottomans developed some politics useful to revitalize the commerce and the means of exploiting the resources ${ }^{53}$ fact that helped less significant economic groups to develop their own commercial activities ${ }^{54}$. Without having a central status among the most important economic agents of the Empire, their role cannot be denied when speaking about regional or local development or about speculating some contexts beneficial for assuring their survival, the perpetuity of some traditional practices and the adaptation to a world in change.

Far from being a "community" predominantly mercantile ${ }^{55}$, the commercial activities developed by the Morlachs in Dalmatia, as reflected by the Venetian documents, help in understanding their nature. The Morlachs from Dalmatia practice a type of commerce very similar to the Vlah commerce, if is not to say identical: it is a commerce practice with the caravans, transports products resulted from personal production or bought from different producers met along the journey; they cross areas difficult to cross and connect communities from both sides of a mountainous chain; this commerce involves skilful individuals familiar with the opportunities granted by different geographic spaces. It can be said that the involvement of the Morlachs in these commercial activities might emphasize a richer layer of Morlachs/Vlachs, but much more open to the assimilation by the low-lands communities. Also, the frequency of these journeys from the inner Balkans toward the coast towns came with a familiarity of the customs and rules of the markets and with openness toward their respect and exploit in order to reach particular achievements. This aspect is mostly visible when analysing the commerce with cereals brought from the Ottoman territories. This commerce was constant part in the Morlachs trade and it easily became subject of smuggling especially after the Sultan`s decision to stop their exports ${ }^{56}$. Nevertheless, the

53 Traian Stoianovich, The Conquering Balkan orthodox merchant, "The Journal of Economic History" 1960, vol. 20, no. 2, p. 235.

54 Ibidem, p. 237.

55 A good example for such a type of community, mountainous and pastoral, but clearly defined ethnical, social and geographic is presented in Patrice Poujade, Une société marchande. Le commerce et ses acteurs dans les Pyrénénes moderne, Mirail 2008.

${ }^{56}$ Les documents ottomans consérves aux archives de la maison d'Este à Modena, in: IX. Türk Tarih Kongresi, vol. 2, Ankara 1981, p. 825: Commandamento del (...) sopra la sublime curia (...) tratta delli 
Morlach caravans carrying cereals into the Dalmatian towns and buying salt were emblematic for identifying their traditional role.

Opportunity is the main element that defined the Morlach commerce in Dalmatia. The need to sell the exceeding products obtained from grazing sheep leaded to a specialization of the Morlachs and to their identification as main providers for significant quantities of cheese ${ }^{57}$, wool, sheep, lambs and wethers ${ }^{58}$. This traditional practice develops in a context in which the demand increased in Dalmatia while the Venetian interest, expressed clearly and directly for them, was not so high (the Morlach products took the way of Venice only through the mediation of the local merchants being sold al Dalmatian products together with others of local production). Because of that the Morlach trade become an activity advantageous for all the involving parts without monopolizing the economic life of Dalmatia.

Additionally, the opportunity seems to be the element to connect the two branches of the Morlach trade: one based on the commerce with subsistence goods, covered by a more important trade with products of a higher value for the economic development of Dalmatia and for the Western provinces of the inner Balkans. Arriving in Dalmatia to buy salt, of a lower quality (the high-quality salt was subject of the Venetian monopoly, while the bad salt was used by the Morlachs mainly for the alimentation of their animals), they bring different other manufactured products and buy merchandise impossible to get on other ways.

All of these helped the Venetian treasuries to obtain a lot of benefits: a good profit from selling large quantities of salt, cheap subsistence products and selling market for local merchandise. If is to consider the income resulted from the Morlach trade the amounts mentioned in different documents are quite large. The largest amount is mentioned by the former inspector Antonio Diedo in his report and counted 400.000 ducats per year ${ }^{59}$ (he includes in this amount the income from the commerce with horses). Either this income was so big or not, for Venice was enough to allow it because it speared the Republic with the obligation to bring vital products for other, more re-

formenti per foura del regnio ai di 15 del ramazan 962, cioe ai di 21 d'agosto 1555; Bruno Simon, Contribution à l'étude du commerce vénitien dans l'Empire Ottoman au milieu du XVIe siècle (15581560), in: "Mélanges de l'Ecole française de Rome, Moyen-Age, temps modernes" 1084, vol. 96, no. 2.

57 Danko Zelić, Proclamationes šibenskoga kneza Fantina de Cha de Pesaro (1441.-1443.), "Povijesni prilozi”" 2008, vol. 35, p. 183; Ante Birin, Šibenski bilježniji-Petar pokojnoga Ivana (1453.1454.), "Povijesni prilozi" 2012, vol. 42, p. 156; Florence Sabine Fabijanec, Le développement commercial de Split et Zadar aux XVe-XVIe siècles: un commerce transitaire entre l'Europe et la Méditerranée, Saarbrücken 2011.

58 Some examples can be found at Ivan Pederin, Šibenik (Sebenico) nel basso Medioevo fino al 1440, "Archivio storico Italiano" 1991, vol. 149.

59 Š. Ljubić (ed.), Commissiones, vol. 3-A, p. 3 (Diedo). Unlike Antonio Diedo, Joannis de Quarzonibus stated in his report that the income resulted from the salt trade made by the Morlachs was not worth considering because the commercial exchange was conditioned by the arrival of the caravans which could not be foreseen or scheduled: idem, Commissiones, vol. 3-J, p. 97 (Quarzonibus): “et se non fosse il rescatto delli Sali, che si vendono alla giornate alli Morlaci, li quali non ho messo a conto dell'entrada per non esser cosa ferma". 
mote provinces of the state and kept its commercial policy according to which all the important products had to pass through Venice. Equally Serenissima kept untouched the status of the Dalmatian town, as important town ports and commercial scalas. By accepting the internal trade practiced by the Morlachs, with or without large expenses from its side, Venice assured the fidelity of the Dalmatian towns, assured the protection of the routes toward the Ottoman provinces and of the border and controlled the ways of maintaining the fundaments of the peace with the Islamic neighbour. All these elements assure viability and continuity for an opportunistic trade. The exploit of an opportunity grants to the Morlachs a privileged status, expressed through some exemptions from transportation taxes, lower fees for buying some products and even exemptions from some of the sales taxes.

From a different point of view, the documents mentioning the Morlachs being involved in commercial activities are also relevant for the diplomatic relations in the border region of Dalmatia. The manner in which the Morlachs, as Ottoman subjects, develop their trade and its consequences mirrors the respect of the peace agreements between Republic and the Porte and also the efforts for a peaceful and fruitful collaboration between the regional officials of the two powers. A representative of the Ottoman state had a residence in the Venetian territory ${ }^{60}$, Venetian groups of stratioti accompany and protect the Morlach caravans while present in Dalmatia ${ }^{61}$, and the obtained income was divided between the regional officials as stipulated by the agreements concluded in Constantinople. Any deviation, abuse or intention to deceive was sanctioned in shortest time, fact that assured a space sure enough to develop this opportunistic traditional trade. The collaboration between the two states is even more relevant and visible in the case of the Morlachs since it appears as an alternative to the maritime Ottoman commerce, affected by the attacks of the pirates or the corsairs active in the Adriatic ${ }^{62}$.

${ }^{60}$ See also Dana Caciur, Discussing regional customs: The conflict between Filippo Bragadin and Cussein Potoclia and the Morlachs of Dalmatia in the mid-sixteenth century, in: Reform and Renewal in Medival East and Central Europe: Politics, Law and Society, eds. Suzana Miljan, Éva B. Halász, Alexandru Simon, Cluj-Napoca-Zagreb-Londra, 2019, p. 467-492.

${ }^{61}$ Such a situation occurred in June 1547 an made the subject of many letters dispatched to Venice, Constantinople and back to Dalmatia. At that time a Morlach caravan with 40 horses was attacked by the Uskoks and the Venetian authorities had to convince the Ottoman ones that the appointed stratioti accompanied the caravan until they left the Venetian territory; ASVe, Senato Deliberazioni Secrete (SDS), reg. 65 , p. $84 \mathrm{r}-85 \mathrm{v}$ and $133 \mathrm{r}-\mathrm{v}$.

62 Maria Pia Pedani, Ottoman merchants in the Adriatic. Trade and Smuggling, "Acta Histriae" 2008, vol. 16, p. p. 159-160. 


\section{OUTLAWS AND MALEFACTORS}

Notwithstanding, the Morlachs were far better known as malefactors, merciless cold blood outlaws or public enemies. Probably the most popular of their description was made by one of the former inspectors in Dalmatia, Giovanni Battista Giustinan in his report at the end of the mandate. Speaking about the people living the mountainous areas of Dalmatia he noted that 'all the inhabitants are named Morlachs, they have a rather fierce appearance than a human one; they stay in hide near the roads, plunder and kill the passers and steal their goods: is it praise of worthy the one who escape their attacks ${ }^{63}$. Similar descriptions can be found in many other documents, and mentions about the fear provoked by the Morlachs appearance became a recurrent theme for the travel accounts so popular for the $18^{\text {th }}, 19^{\text {th }}$ and $20^{\text {th }}$ centuries. For the chosen time frame however, the outlaw activities of the Morlachs appear as a natural consequence of the politic and economic instability, and also as reaction of some individuals living in a border area where the administrative limitation were very flexible. Moreover, their criminality came together with the lack of the adaptability of this type of traditional and independent communities closed to the rules of some settled societies.

Here I will present only two examples, one for the period when Venetian Dalmatia was neighbouring the Hungarian Kingdom and the other one from the period when the Ottomans replaced it. In $6^{\text {th }}$ of January $1432^{64}$ a letter dispatched in the name of doge Francesco Foscari and addressed to Iacopo Gabriel, the count and captain of Šibenik is resumed the case of two Vlachs who stole horses from other Vlachs (equos Morlachorum, sive Vlahorum) established in the hinterland of Trogir. The guilty Vlachs were caught and kept in the Šibenik's prison, city where the count was willing to judge and punish them. This case required the intervention of the doge because the count of Trogir also wanted to judge and punish the Vlachs and he even invoked in his favour a Senate decision from $22^{\text {nd }}$ of March 1422 according to which all those guilty for similar actions could be judged in any place of Dalmatia. Another argument for the Vlachs being judged in Trogir was represented by the count's desire to recover in a shorter time the stolen horses to the greater benefit of the Morlachs. On the other side, the count of Šibenik could not allow the transfer of the Vlachs in Trogir because he was afraid of the intervention of the affected Vlach families willing to apply their own form of justice: the vendetta (vendetta de sangue; sicut est moris Vulahorum). According to this document the Vlach vendetta would have been applied equally to the thieves and to the authorities of Šibenik which helped in catching them and delayed the traditional justice. To avoid any unpleasant consequence the Senate and the

63 Š. Ljubić (ed.), Commissiones, vol. 2 p. 235 (Itinerario B. Giustinian): “tutti sono chiamati Morlachi, li quali hanno piuttosto aspetto ferino che humano, et stando ascosi presso le strade, rubano et assassinano i passagieri, et i spogliano; et estimano grand laude il viver di rapina".

${ }^{64}$ MNL, Diplomatarium Sibenicense. 28135 (U1201); a resume of this document is also published in Vincenzo Miagostovich, Per una cronaca Sebenicense, "Rivista Dalmatica" 1908, vol. 4, no. 2, p. 171. 
doge established for the two Vlachs to remain in prison in Šibenik and to be judged according to the rules and laws of the state.

This document puts face to face the 'civilized' world of the Venetian laws and the "barbaric" one of the Morlachs/Vlachs. Vendetta, the death penalty for those who caused damages to a family, was a judicial practice very common in the rural environment of the Western Blakans ${ }^{65}$, the Vlachs being those who carried it in Dalmatia and also in Istria ${ }^{66}$. Because of that it is placed together with the life in catuns, the seminomadic transhumance and the caravan commerce, among the Vlach elements traced in the Morlach portray. The document also argues, for the period previous to the establishment of a Venetian-Ottoman border, for the equality between the Vlach-Morlach exonyms. However, it must be said that the documents is written in Latin and Vlach was, for the Venetian, the Latin translation for Morlachs as it mentioned by the document itself: equos Morlachorum, sive Vlahorum.

After the neighbours changed the punishment of the Morlach malefactors became even more difficult because it was harder to identify the culprits and not to apply the justice when the culprit was not a subject from Venetian Dalmatia. It happened mostly because these Morlachs malefactors acted together with the martolossi (irregular soldiers of the Ottoman offensive) with which were often confused. In spite of this, whenever such a situation occurred the Venetian authorities acted in similar ways. It happened in 1530 as it is mentioned in a letter sent by Nicolao Marcello, the count and captain of Šibenik to the Venetian Senate ${ }^{67}$. He reported the arrest and punishment of two Ottoman subjects, Michiel Tergliemach and Michiel de Helia, guilty for robberies in the Dalmatian hinterland. Both the culprits were martolossi and relatives of Murat, regional Ottoman functionary and friend of the Venetian count. Their arrest happened during the mandate of the previous count, Benedetto Velier, and Murat together with other Ottoman officials demanded their release for judgement under the Ottoman laws. Since this was a decision that could not be taken by a Venetian himself, Nicolao Marcello asked for the Senate`s advice. However, in order to avoid any diplomatic dispute, the count of Šibenik was considerate enough to inform about the

65 Christopher Boehm, Blood Revenge: The Anthropology of Feuding in Montenegro and Other Tribal Societies, Lawrence 1984; Ugo Inchiostri, Di alcuni aspetti del diritto penale nei documenti e statuti dalmati del medioevo, "La rivista Dalmatica" 1928, vol. 10, no. 1, p. 18-19; Joanna Carraway Vitiello, Public justice and the criminal trial in late medieval Italy. Reggio Emilia in the Visconti age, LeidenBoston 2015.

66 ASVe, SDM, reg. 27, p. 99r; Bernardo Schiavuzzi, Cenni Storici sull'etnografia dell'Istria, in: "Atti e memorie della Società Istriana di Archeologia e Storia Patria" 1902, vol. 18, p. 117: "ciò che spaventava i poveri vecchi abitanti era il giuramento di vendetta dai Morlacchi detto "vrasba", pel quale tutti i parenti, amici e benevolenti giuravano di vendicarsi dei denunciatari, sicchè nessuno ardiva di farsi accusatore degli assassini, dei ladri ed in generale dei malfatori, per non incurrere nelle vendette dei denunciati".

67 ASVe, $C C d X$, b. 280. 
case the sanjack-bey of Bosnia ${ }^{68}$, Ibrahim Pașa ${ }^{69}$, many of the local officials and even the Venetian bailo in Constantinople. The answer of the Venetian Senate is nevertheless what interests us more. It was written in a resume on the back of the document and established that the two Morlachs (duos morlachos) should not be released in the hands of Murat and that they should be judged by the Venetian authorities. It is once more proved that, even if the authorities were aware about the distinction between the people moving in Dalmatia these distinctions did not matter so much when it came to apply the justice or to interfere for assuring a peaceful coexistence.

Obviously these two short examples do not intend to resume or to synthesize the outcomes of the Morlachs criminal activities. A narrow province under constant pressure of war and populated by many different 'out-comers' forced the authorities to solve each case in particular to avoid the escalation of the conflict. Taking into account all these observations, the Morlach outlaws can be considered examples of banditism $^{70}$, especially since their action did not emerge from some form of sanguine malevolence but as a solution for surviving in merciless conditions. High road thefts, killings, kidnappings that increase the slave markets, rapes or animal stealing, all together with cases of complicity with local authorities, the traditional forms of applying the justice (the vendetta) and the close ties with the originating milieu (the community to which the leader belonged $)^{71}$ are features that might convince us to speak about the $15^{\text {th }}-16^{\text {th }}$ centuries Morlachs as bandits.

In fact, when discussing the crimes involving the Morlachs some important distinctions could be observed: Morlachs outlaw inhabitants of Venetian lands and Morlach malefactors arriving from the Ottoman territories. This differentiation is relevant because it justified the distinct measures applied by Venice in order to react or to stop some disturbing events. So far, we could observe that when the outlaw Morlach was a Venetian subject (colonised subject in Venetian administrated village) his punishment required a public announcement for his need to appear in front of the justice $^{72}$. If a number of days passed without his arrival then he was banished away from

68 The count of Šibenik dispatched these letters addressed to the Ottoman officials using a messenger mentioned in the document with the term olacho. This example might contribute to the often confusion suggesting that the Balkan Vlachs were the messengers of the Ottomans. Once more, without denying the possibility I stress over the importance to contextualize the hypothesis. More about this see: Radu Păun, Les Valaques du Montaigne. Les metamorphoses d'un mot, "Revue Romaine d'Histoire" 1995, vol. 34, no. 1-2, p. 207-211; Ovidiu Cristea, Puterea cuvintelor. Știri și război în sec. XV-XVI, Târgoviște 2014, p. 185.

69 Behija Zlatar, Gazi Husrev-beg, Sarajevo, 2010; James Tracy, Balkan Wars. Habsburg Croatia, Ottoman Bosnia, and Venetian Dalmatia, 1499-1617, Lanham 2016.

${ }^{70}$ Neva Makuc, Noble violence and banditry along the border between the Venetian Republic and the Austrian Habsburgs", "Mediterranea-ricerche storiche" 2015, vol. 12, p. 212.

71 Considering the aspects defining a bandit as established by Eric Hobsbawm, Bandits, London 2000. Is worth considering the fact that the author stressed over the fact that all the bandits had a pastoral origin, similar for the case of the Balkan hayducs, that they benefited of an autonomy granted by a traditional life style, by their past and specific.

72 ASVe, SDM, reg. 25, p. 173r-v: Antonio Carlich Murlacho and his companions made some acts of violence and robberies in the summer of 1540 , one of them ending with the death of a soldier/ knight in 
all the Venetian possessions, from all of its ships and an attractive reward was established for those willing to offer information about the criminal. This form of punishment, the banishment of a criminal, was defined by the Venetian laws under the term of bando (lat. med. bannum). It can be found among the capital punishments, together with death penalty, life sentence or forced service as rower on the Venetian galleys for a specific amount of time ${ }^{73}$. On the other side, when the Morlach offender was an Ottoman subject then his punishment was negotiated with the Ottoman representative who had the right to judge him ${ }^{74}$.

\section{SOME CONCLUSIONS}

Whether before 1409 the functioning of the Morlachs in Dalmatia was typical for the Vlachs, it would change because of the rules and decisions applied by the Venetian authorities. To exemplify: the military character of the Vlach groups of the $14^{\text {th }}$ century, usually visible in the context of the conflict between the Dalmatian coast towns and Mladen Šubić of Bribir, could be also observed during the $15^{\text {th }}$ century in the context of the requirements imposed by the Croatian nobles and the Hungarian crown. However, more visible changes appeared once the Ottoman offensive reached the Western Balkans. If in the first periodof the Venetian administration in Dalmatia, Serenissima did not pay too much attention to the Morlach military incursions (Vlach, according to the Hungarian sources speaking about the same events) and tended to solve them with diplomatic means, the fall of Bosnia and the establishment of a border with the Ottomans determined a change of attitude. Venice organized a mirror reaction to the Ottoman offensive actions, using mainly the immigrants who fleed from the Ottomans. The Morlachs became inhabitants of some border fortresses in charge with the protection of the lands by the attacks of the Ottoman soldiers, but they also become members of the Venetians troops of stratioti along with the Croatians and Dalmatian people.

The fall of Bosnia, followed by an intensified Ottoman offensive toward the Western Balkans, and an increased number of immigrant waves are extremely important for the history of the Morlachs and for the understanding what lays behind their name. Up to that moment in Dalmatia lived a Vlach population identified by

service of the captain of Raspo.

${ }^{73}$ Edoardo Rubini, Giustizia veneta. Lo spirito veneto nelle leggi criminali della Repubblica, Venezia 2010, p. 99-100; Neva Makuc, op. cit, p. 214: "the characteristic practice of the Venetian authorities namely sentencing criminal offenders to banishment. The most severe penalty was a bandocapitale, which meant that anyone had the right to kill an exile with impunity".

${ }^{74}$ Some other examples can be found in Dana Caciur, Soluțiile oficialilor venețieni din Dalmația la practicile criminale ale morlacilor în decursul secolului al XVI-lea. Cazul: Milia Popovich/Melia Popović, in Povestiri intretăiate. Istoria în cheie minoră, ed. Ovidiu Cristea, Cetatea de Scaun, Târgoviște 2016, p. 295-314 (The solutions of the Venetian officials from Dalmatia to the criminal activity of the Morlachs during the 16th century. The case of Milia Popovich/Melia Popović). 
the Venetians as Morlach (either as a local etiquette adopted by the Venetians or as a Byzantine name of the Black Vlachs inherited by Venice) known for sheep grazing, caravan commerce and involved in military activities in the name of the Hungarian crown. To these groups of Morlachs/Vlachs added some other new ones. Since these new Morlach waves, fugitive from the Ottomans, might as well gather Vlachs, Serbians, Bosnians, and others, it is very likely that the Venetian authorities chose to use the same 'name' to refer to them without taking too much in consideration their ethnicity (with today's meaning). The reactions were understandable since it was applied mainly to the poor people who abandoned their properties carrying with them only the animals, while the richer refugees had a bigger chance to express their ethnical appurtenance and to be recognised accordingly.

This way the Morlach communities increased in Dalmatia until 1526. After this moment, when the Ottoman troops were concentrated near Buda and oriented toward the Central Europe a relative peace reigned in Dalmatia. It lasted until the Venetian Ottoman war of 1537-1540 and allowed Venice to prepare its defensive and demographic security resources. In this context the Morlachs were not anymore exclusively shepherds, soldiers or merchants, but practiced all these activities according to the opportunities created by the states in which they lived. This is why for the $16^{\text {th }}$ century history of the Morlachs is essential to understand that the only clear distinction is given by the phrases: 'the Morlachs our subjects (Venetian)' and 'the Morlachs the subjects of the Sultan'. The presence of these phrases in the Venetian documents reflected different statutes, obligations and privileges.

In most of the cases the Morlachs form Dalmatia were Ottoman subjects arrived in the Venetian province from the outside. From this situation many other particularities derived and made a clear and definitive identification of the Morlachs very difficult. They lived in a space claimed equally by the Venetians and the Ottomans. On one side this was considered an argument for the construction of a border region and of some complicated diplomatic relations, but on the other side their life in this 'unsettled' space kept the details of their life traditional and closed for many of the external changing inputs. The Morlachs who lived in villages that were an object of the negotiations between the regional and central authorities, were Ottoman subjects and even haraç payers. They lived those villages mainly during the winter months arguing for a lifestyle specific for shepherds and their semi-nomadic movement made the establishment of their rightful ruler very uncertain. However, their custom of being periodically present in Dalmatia helped them to create strong relations with the locals. The political changes begun with the inclusion of Zara in the Venetian Republic which did anything else but to intensify the process of inclusion and assimilation in the society of Dalmatia. It was the Venetian administration that acted like leverage for this Morlach subtle transformation. The villages and the fields rented from the local nobles or from the Venetian counts and captains, the animals they were hired to take care of, the extraordinary commercial opportunities and also the attractive promises made by Venetian authorities who wanted the Morlachs became their subjects could be treated as equal or even more promising alternative to the life in the Ottoman Empire. 
The paradox we encounter is the one that assured the survival of a very distinct community which began to cooperate and to respect the rules they had to follow. Venice wanted to use for its own benefit the local specifics and the ways the people of new provinces of Stato da Mar lived. This way 'the Morlach matter' fall most of the time in the charge of the regional officials, the involvement of central authorities being rather consultative. This is also the reason why we lack an ethnical definition of the Morlach communities other than the one promoted by the intellectuals or historians of the time. In the politic games and administrative decisions, its relevance was not of importance.

On the other side, this paradox was created by the Morlachs themselves. A traditional closed and independent lifestyle granted the Morlach communities with the possibility to choose the rules to respect, the opportunities to take and even the state to whom to obey. The entire researched period emphasized a game of testing the patience of the Dalmatian authorities and even to the neighbouring Ottoman ones, especially because it was not a single accepted way to interact with the Morlachs. Thus, is some villages were illegally inhabited by the Morlachs, others were rented and another ones were granted to be colonized: if some products could be sold on the Dalmatian markets only following the Venetian-Ottoman commercial agreements and respecting some established prices, quantities and locations (for salt and cereals), other products (manufactured, of animal origin, obtained from intermediaries) could be sold much more free because the quantities were small and necessary for daily consume. Also, if some Morlach shepherd graze and water their flocks only in places where the authorities allowed them to, some other ignore the interdiction to enter the vineries, corps and particulars pasturelands. In a similar way happened the things when it comes to answer in front of justice. If some Morlach malefactors respect, willingly or not, Venice's punishments others recognise only the traditional forms of punishment (like vendetta), and while some Morlachs asked for forgiveness from the Venetian officials, others attacked them. Seen from above all these aspects describing the Morlachs from Dalmatia during the $15^{\text {th }}$ and $16^{\text {th }}$ centuries can mostly to emphasize the complexity of the Morlach life style as it emerges from the Venetian perspective.

\title{
BIBLIOGRAPHY
}

\author{
Sources: \\ MNL - Hungarian National Archives (Magyar Nemzeti Levéltár): \\ Diplomatarium Sibenicense \\ ASVe - State Archives of Venice (Archivio di Stato di Venezia): \\ Capi di Consiglio dei $X[\mathrm{CCdX}]$, \\ Collegio. Lettere secrete, \\ Senato Deliberazioni Mar [SDM], \\ Senato Deliberazioni Secrete [SDS].
}




\section{Publications:}

Alacevich Angelico, Pagine della storia di Sebenico, Tipografia del comando truppe Dalmazia (24 divisione), Šibenik 1920.

Alberi Eugenio, Le relazioni degli ambasciatori veneti al Senato durante il secolo decimosesto, vol. 3, part 3, Florența 1855.

Antolini Nicola, Slavi e Latini in Istria tra cinquecento e novecento: origine storiche e problem del contest multi-etnico istriano, "Storicamente" 2006, vol. 2.

Benvenuti Angelo de, Storia di Zara dal 1409 al 1797, Milano 1944.

Berend Nora, At the gate of Christdom: Jews, Muslims and "Pagans" in medieval Hungary, c. 10001300, Cambridge 2001.

Birin Ante, Šibenski bilježniji - Petar pokojnoga Ivana (1453.-1454.), "Povijesni prilozi” 2012, vol. 42.

Boehm Christopher, Blood Revenge: The Anthropology of Feuding in Montenegro and Other Tribal Societies, Lawrence 1984.

Braudel Fernand, Mediterana și lumea mediteraneană în epoca lui Filip al II-lea (The Mediterranean and the Mediterranean world in the Age of Philip II), Bucharest 1985.

Bujan Solange, La Chronique du prêtre de Dioclée. Un faux document historique, "Revue des etudes byzantines" 2008, vol. 66, p. 5-38.

Caciur Dana, Soluțiile oficialilor venețieni din Dalmația la practicile criminale ale morlacilor în decursul secolului al XVI-lea. Cazul: Milia Popovich/Melia Popović, in Povestiri intretăiate. Istoria în cheie minoră, ed. Ovidiu Cristea, Cetatea de Scaun, Târgoviște 2016, p. 295-314.

Caciur Silvia-Dana, Migrații spontane și organizate în teritoriul Zarei (Zadar-ului) la mijlocul secolului al XVI-lea. Cazul Morlacilor Istrieni, "Studii și materiale de istorie medie" 2016, no. 34, p. 73104.

Caciur Dana, Discussing regional customs: The conflict between Filippo Bragadin and Cussein Potoclia and the Morlachs of Dalmatia in the mid-sixteenth century, in: Reform and Renewal in Medival East and Central Europe: Politics, Law and Society, eds. Suzana Miljan, Éva B. Halász, Alexandru Simon, Cluj-Napoca-Zagreb-Londra, 2019, p. 467-492.

Caenazzo Tomaso, I Morlacchi nel terriotiro di Rovigno, in: Atti e memorie della Societa Istriana di Archeologia e storia patria, Parenzo 1885, p. 129-140.

Cristea Ovidiu, Puterea cuvintelor. Știri și război in sec. XV-XVI, Târgoviște 2014.

Doumerc Bernard, L'Adriatique din XIII eme au XVI eme siecle, in: Histoire de l'Adriatique, ed. Pierre Cabanes, Paris 2001.

Eric Dursteler, Commerce and Coexistence: Veneto-Ottoman trade in the early modern Era, "Turcica" 2002, no. 34, p. 105-133.

Fabijanec Florence Sabine, Le développement commercial de Split et Zadar aux XVe-XVIe siècles: un commerce transitaire entre l'Europe et la Méditerranée, Saarbrücken 2011.

Fuerst-Bjeliš Borna, Imagining the Past: Cartography and Multicultural Realities of Croatian Borderlands, in Cartography - A tool for Spatial Analysis, ed. Carlos Bateria, Porto 2012, p. 295-312.

Grignaschi Mario, Les documents ottomans consérves aux archives de la maison d'Este à Modena, in: IX. Türk Tarih Kongresi, vol. 2, Ankara 1981, p. 819-827.

Goffman Daniel, The Ottoman Empire and Early Modern Europe, Cambridge 2002.

Hobsbawm Eric, Bandits, London 2000.

Inchiostri Ugo, Di alcuni aspetti del diritto penale nei documenti e statuti dalmati del medioevo, "La rivista Dalmatica" 1928, vol. 10, no. 1, p. 2-19.

Juran Kristijan, Doselavanje Morlaka u opustjela sela šibenske Zagore u 16. stoljeću, "Povijesni prilozi" 2014, no. 46, p. 129-160.

Ljubić Šimeon (ed.), Commissiones et relationes Venetae, vol. 1-3, Zagreb 1877-1880.

Ljubić Šimeon (ed.), Listine. O odnošajih izmedju južnoga slavenstva i mletačke republike, vol. 2 (13361347), 4 (1358-1403), 6 (1409-1412), 7 (1412-1420), 9 (1423-1452), 10 (1453-1469), Zagreb 1870-1891. 
Lamansky Vladimir, Secrets d'Etat de Venise. Documents extraits notices et etudes servant a eclaircir les rapports dela Seigneurie avec les grecs les slaves et la Porte Ottomane a la fin du XVe et au XVIe siecle, Saint-Petersbourg 1884.

Luca Lia de, Venezia e le immigrazioni in Istria nel Cinque e Seicento, $\mathrm{PhD}$ thesis, Università Ca'Foscari, Venice 2011.

Luković Miloš, Self-government institutions of nomadic and semi-nomadic livestock breeders in the Balkans and in the Carpathian regions in the late medieval and early modern periods, "Res Historica" 2016, vol. 41, p. 51-94.

Makuc Neva Noble violence and banditry along the border between the Venetian Republic and the Austrian Habsburgs", "Mediterranea-ricerche storiche" 2015, vol. 12, p. 211-226.

Madunić Domagoj, Defensione Dalmatiae: Governance and Logistics of the Venetian Defensive System in Dalmatia during the War of Crete (1645-1669), PhD thesis, Central European University, Budapest 2012.

Mayhew Tea, Dalmatia between Ottoman and Venetian rule. Contado di Zara, 1645-1718, Roma 2008.

Miagostovich Vincenzo, Per una cronaca Sebenicense, "Rivista Dalmatica" 1908, vol. 4, no. 2, p. 161189.

O'Connell Monique, Men of Empire. Power and Negotiation in Venice's maritime state, Baltimore 2009.

Păun Radu, Les Valaques du Montaigne. Les metamorphoses d'un mot, "Revue Romaine d'Histoire" 1995, vol. 34, no. 1-2, p. 207-211.

Pál Engel, Magyarország világi archontológiája 1301-1457, vol. 1, Budapesta 1966, p. 26.

Pedani Maria Pia, Relazioni di ambasciatori veneti al Senato. Costantinopoli (1512-1789), vol. 14, Padova 1996.

Pedani Maria Pia, The Ottoman-Venentian border (15th-18th centuries), Venice 2017.

Pedani Maria Pia, Ottoman merchants in the Adriatic. Trade and Smuggling, "Acta Histriae" 2008, vol. 16, p. 159-160.

Pederin Ivan, Šibenik (Sebenico) nel basso Medioevo fino al 1440, "Archivio storico Italiano" 1991, vol. 149, p. 811-885.

Poujade Patrice, Une société marchande. Le commerce et ses acteurs dans les Pyrénénes moderne, Mirail 2008.

Pust Klemen, "Mi faccio Turco". Migrations from the Venetian to the Ottoman territory and conversions of Venetian subjects to Islam in the Eastern Adriatic in $16^{\text {th }}$ century", in: Adriatic frontiers: communications across cultures, space and rime, la Mediterranean Programme $11^{\text {th }}$ Mediterranean Research meeting, Florence and Montecatini terme 2010, pp. 29.

Pust Klemen, "Le genti della citta, delle isole e del contado, le quale al tutto volevano Partirsi". Migrations from the Venetian to the Ottoman territory and conversions of Venetian subjects to Islam in the Eastern Adriatic in 16 $6^{\text {th }}$ century, "Izvorni znanstveni rad" 2011, vol. 40, p. 121-159.

Rubini Edoardo, Giustizia veneta. Lo spirito veneto nelle leggi criminali della Repubblica, Venezia 2010, p. $99-100$.

Schiavuzzi Bernardo, Cenni Storici sull'etnografia dell'Istria, in: "Atti e memorie della Società Istriana di Archeologia e Storia Patria" 1902, vol. 18, p. 75-120.

Simon Bruno, Contribution à l'étude du commerce vénitien dans l'Empire Ottoman au milieu du XVIe siècle (1558-1560), in: "Mélanges de l'Ecole française de Rome, Moyen-Age, temps modernes" 1084, vol. 96, no. 2, p. 973-1020.

Smičiklas Tadija (ed.), Codex Diplomaticus regni Croatiae, Dalmatiae et Slavoniae, vol. 9, 11 (13421350) 12 (1351-1359), 13 (1360-1366), 14 (1367-1373), Zagreb 1911-1916.

Stefini Tommaso, Irregularità e raporti di forza nella Dalmazia del Cinquecento,"Studi Veneziani" 2010, vol. 59, p. 626-652.

Thallóczy Lajos, Hondika Antal, A horvát véghlyek oklevéltára 1490-1527, Budapesta 1903.

Stoianovich Traian, The Conquering Balkan orthodox merchant, "The Journal of Economic History" 1960, vol. 20, no. 2, p. 234-313. 
Tracy James, Balkan Wars. Habsburg Croatia, Ottoman Bosnia, and Venetian Dalmatia, 1499-1617, Lanham 2016.

Theunissen Hans Peter Alexander, Ottoman-Venetian Diplomatics: the Ahd-names. The Historical background and the development of a category of political commercial instruments together with an annotated edition of a corpus of relevant documents", "Electronic Journal of Oriental Studies" 1998, vol. 1, no. 2, p. 377-392 (1-689).

Trajković-Filipović Stefan, Inventing a saint's life: chapter XXXVI of The Annals of a priest of Dioclea, "Revue des etudes byzantines" 2013, vol. 71, p. 259-276.

Vitiello Joanna Carraway, Public justice and the criminal trial in late medieval Italy. Reggio Emilia in the Visconti age, Leiden-Boston 2015.

Zelić Danko, Proclamationes šibenskoga kneza Fantina de Cha de Pesaro (1441.-1443.), "Povijesni prilozi” 2008, vol. 35, p. 149-191.

Zlatar Behija, Gazi Husrev-beg, Sarajevo 2010. 